\title{
Acceleration of regional housing development in Russia on the basis of industrial housing construction modernization
}

\author{
Larisa Selyutina ${ }^{1, *}$, Tatyana Maleeva ${ }^{2}$ and Natalya Frolova $^{2}$ \\ ${ }^{1}$ Department of Economics and Construction Management, Emperor Alexander I Petersburg State \\ Transport University, 9, Moskovsky pr., St. Petersburg 190031, Russia \\ ${ }^{2}$ Department of State and Municipal Administration, Pushkin Leningrad State University, 10, St. \\ Petersburg sh., Pushkin, St. Petersburg 196605, Russia
}

\begin{abstract}
The article is dedicated to the actual problem of regional housing development. The authors propose to use the existing Russian production facilities of large panel construction, which must be modernized on the basis of modern technologies, as a promising reserve for increasing the volume of housing construction. Currently, EU countries pay considerable attention to cluster strategies as an effective tool for the innovative development of regions and enterprises. Recently, there has been a significant amount of interest to this problem in Russia. It identified distinctive parameters of the formation and implementation of regional cluster construction policies, industrial housing on an innovative basis in comparison with traditional industrial and construction policies. The need for an integrated approach to innovative solutions in the field of technology and construction management has been proved. The need for improving the spatial organization of construction by creating industrial housing construction clusters on the territory of large industrial regions has been justified, which, according to the authors point of view, will help to find a fast solution of the housing problem in St. Petersburg and in Russia as a whole.
\end{abstract}

\section{Introduction}

Housing development is one of the most important tasks of regional authorities, because it provides an increase in tax income to the budget and expansion of the taxable base, as well as helps to meet the needs of the population for high-quality, technologically and technically modern housing, and most importantly, to improve the quality and standard of living [1-3]. We can assess the level of regional economic development according to the rate of provision of the population with adequate quality housing.

The condition of the housing stock, the quality of housing and public utility services, as well as housing market development have a significant impact on the investment climate of the territory. Increasing the rate of housing supply, as well as improving its quality will

*Corresponding author: ya.slarisa@yandex.ru 
contribute to the growth of consumption and provide conditions for attracting labor resources to the region [4-6]. All this stimulates economic development in order to better meet the needs of the population, raising its living standard, and, consequently, welfare [79].

The average Russian rate of provision of the population with living space on average per person $\left(25,2 \mathrm{~m}^{2}\right)$ divides all the subjects of the Russian Federation into two groups equal in the number of regions - below the average and above the average level. Moreover, each group includes regions where the level of housing provision considerably differs not only from the average rate in the country, but from most regions in the group as well.

Region distribution by the level of housing provision of the population in 2017 is demonstrated in figure 1. Regions are located in the order according to Rosstat (also known as Russian Federal State Statistics Service) - that is by Federal Districts (from 1 to 18 Central Federal District; 19-29 - Northwestern Federal District; 30-37 - Southern Federal District; 38-44 - North Caucasian Federal District; 45-58 - Volga (Privolzhsky) Federal District; 59-64 - Ural Federal District; 65-76 - Siberian Federal District; 77-85 - Far Eastern Federal District).

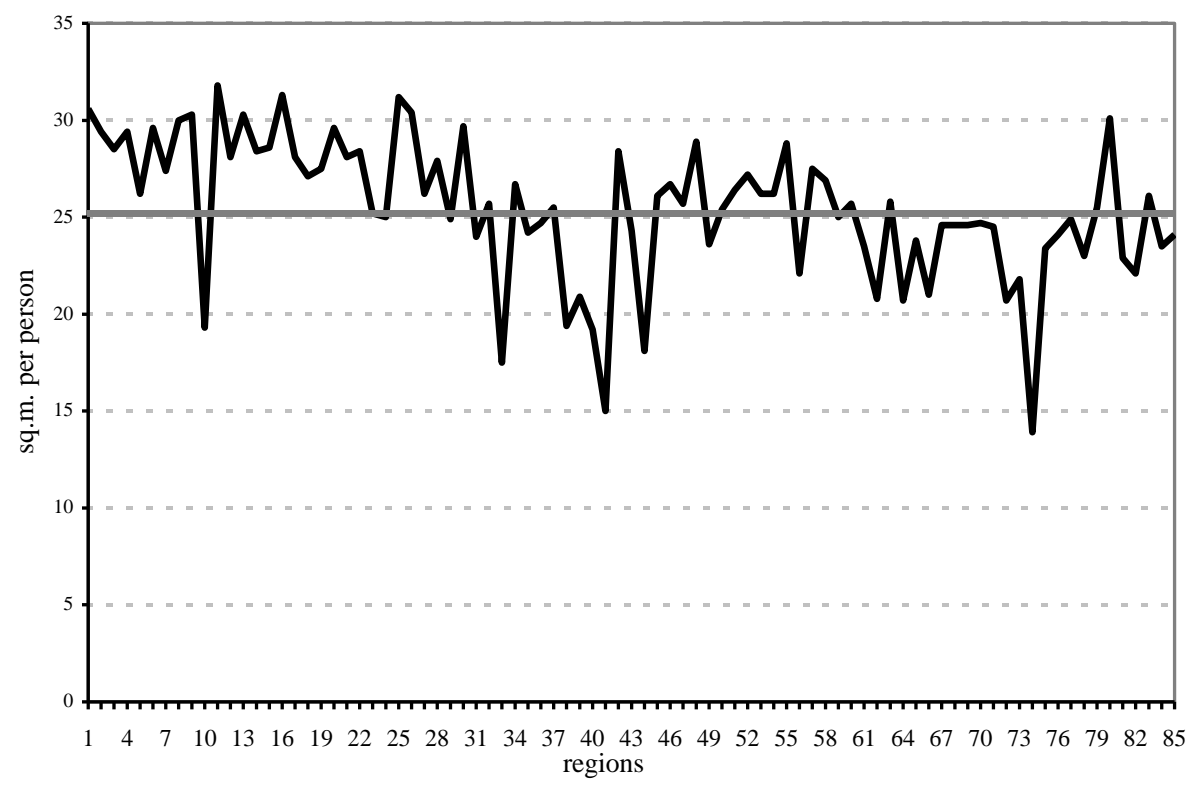

Fig.1. Provision of the population with a living space as per 1 person in regions of the Russian Federation in 2017

The rate value for the provision of population with living space as per 1 person in regions of the Russian Federation varies from $31.8 \mathrm{~m}^{2}$ in the Moscow Region down to 13.9 $\mathrm{m}^{2}$ in Tyva. 47 regions show the higher level than the all-Russian one, 37 - the lower and one corresponds to the all-Russian level [10].

In the country as a whole, the volume of housing construction in recent years has been at a rather high level, although it is slightly decreasing lately. In 2018, there were $75 \mathrm{mln}$ sq.m of the total area of residential premises supplied (including St. Petersburg - more than 7 mln sq.m), in 2017 - $79.2 \mathrm{mln}$ sq.m, in 2016 - $80.2 \mathrm{mln}$ sq.m, and in 2015 - $85.3 \mathrm{mln}$ sq.m. However, the difference in the rates of construction of residential buildings among the Russian regions is very large. 13 regions have more than half of the delivered total area of residential buildings in Russia, and the remaining half accounted for 72 subjects, i.e. construction volumes there are usually very low. 
It is obvious that the construction of a sufficient number of housing, considering the supply up to $100 \mathrm{mln}$ sq.m by 2020 , is possible only due to major innovative changes in the construction industry [11]. These changes include:

- transition to frame and cast-in-place (and prefabricated frame) housing construction, the use of stationary form construction (or permanent form technology);

- transition from the construction of houses directly on construction sites to modular prefabricated construction;

- introduction of various new materials such as porous bricks, composite materials and plastics. Decrease in material consumption;

- introduction of rapid construction technology using fixed formwork from polystyrene foam;

- integrated solution of energy saving in residential buildings, introduction of "passive" and "active" house concepts;

- implementation of "smart" and "green" house concepts;

- introduction of effective methods of waste disposal and wastewater treatment (centrifugal and membrane technologies).

Those specified above elements are the main basis for a modern approach to the revival and further modernization of industrial construction.

\section{Materials and Methods}

Today, the material and technical base of such construction in the Russian Federation is not sufficiently and efficiently used. If we set a task to provide the total living space for citizens of the Russian Federation in the amount of $28-35 \mathrm{~m}^{2}$ per 1 person, then it is necessary to modernize the current industrial housing construction base and develop new facilities on an innovative basis.

At present, only half of 409 existing house-building factories continue to operate, producing $10-12 \mathrm{mln}^{2}$ of houses annually, although their production capacity is $25-35$ $\mathrm{mln} \mathrm{m}^{2}$. At the same time, only 30 of 210 operating factories correspond to modern production facilities.

By the way, the infrastructure of those facilities that do not operate any more as housebuilding factories can be used or redesigned as the production for housing construction. The majority of house-building factories operating in Russia produce a series of residential houses, designed in 1970-1990 [12, 13]. The quality of these outdated series, developed 2030 years ago, does not meet modern requirements not only from the point of view of the consumer, but also from the position of the state.

You can't beat the large-panel housing technology by its construction cost and time period. But the consumer qualities of panel housing do not fully meet the needs due to practical impossibility of changing the arrangement and partitions, uniting spaces or its transformation $[14,15]$. At the same time, the presence of room-sized intermediate slabs and a one hidden seam provide not only good aesthetics of the apartment, but also make it cheaper. However, the greatest flexibility of architectural and planning solutions will be appropriate to the panel system with a wide pitch of bearing cross-walls. This requires the use of hollow core slabs with pre-tensioned reinforcement $[16,17]$.

To expand the possibilities of prefabricated panel construction using precast reinforced concrete, it is better to use a frame system, since it is universal and has become very common in the construction of residential and public buildings. The combination of frame elements with panel structures allows finding innovative solutions in modern construction.

At present, precast concrete equipment and technology are so universal that allow producing not only according to an open type designs, but also providing a full range of precast reinforced concrete for residential and public facilities, including engineering 
structures. At the same or different cooperating enterprises, together with panel structures, we shall produce hollow-core slabs made on long stands; frame elements (columns, bolts, beams and bars, pylons) - all of these products fit perfectly in combination with large-panel internal and external walls into new residential buildings and public facilities.

Thus, we can observe a replacement of large-panel housing construction in its pure form on panel-frame house construction (PFC). PFC is a new innovative solution of industrial construction, new opportunities for architects, designers, engineers, managers to meet consumer demand for modern comfortable houses.

PFC removes all existing restrictions typical to large-panel construction (LPC). The flexibility of architectural and planning solutions is that they are exactly what the consumer's family needs with a possible change of the apartment plan. The PFC system provides capabilities that exceed the monolithic construction due to architectural and planning solutions. In monolithic buildings you can't bridge over span of more than $7.2 \mathrm{~m}$ without intermediate supports and a significant cost increase, whereas a panel-frame system allows spans up to $9 \mathrm{~m}, 12 \mathrm{~m}$ or more when using hollow-core slabs [18].

\section{Results and discussion}

The revival of industrial construction in Russia should be carried out according to quantity and quality terms. At the same time, the housing problem in Russia will not be solved at all in the near future without such a revival. Therefore, it is necessary to activate all idle LPC plants, provide $100 \%$ production capacity and build new plants. The revival of industrial housing construction should be performed on an innovative basis through modernization with the transition to flexible technological schemes and a panel-frame construction [19].

The most telling example of such revival on an innovative basis is the "Grad" factory foundation in Naro-Fominsk, Moscow Region in early 2015 [20]. The company has become the largest house-building factory $(\mathrm{HBF})$ at the federal level, established in Russia over the past 30 years. The capacity of new HBF reaches 525 thnd $\mathrm{m}$ of products per year, 450 thnd $\mathrm{m}^{2}$ of which is an apartment area and 75 thnd $\mathrm{m}^{2}$ are buildings of social and cultural significance. Unlike HBF of the previous generation, the Grad's product range is not tied to a specific series. Modern equipment allows the plant to produce practically an unlimited number of houses under any architectural planning project, simultaneously. Its use will minimize costs:

- reduce by $70 \%$ the labor costs allowing the use of new generation wire-welding machines;

- reduce by 2 times the time of loading and unloading work;

- eliminate the need to operate the crane due to the use of unloading semi-trailers.

"Grad" HBF is a high-tech, design and production complex using the most modern world technologies and innovative developments of RUSNANO. Due to the large production volume, energy saving equipment and automation system, the cost per square meter of a residential building does not differ much from old HBF's products [21]. And the more innovative house-building factories of this type are established in our country, the better quality of houses we get, the faster we solve the housing problem. The experience of modernization of house-building factories in a number of cities of the Russian Federation, the existing foreign experience allows us to conclude that it is necessary to closely link innovative solutions in the field of technology with innovative management solutions. These solutions include the following:

1. The authors revealed that presently there are two conventional technological systems for industrial housing construction - rigid (inflexible) and flexible technological systems. During the USSR period, all LPC factories were built using the inflexible technological system. The main feature of this technology is that each precast concrete product needs its 
own metallic form with a rigid non-removable (permanent) board and pallet layout. This allowed those factories to produce a large number of residential buildings in the absence of their diversity and the impossibility of switching over to new, advanced, more costeffective series. This scheme is based on a compact cassette equipment [22]. According to the flexible technological scheme there are new LPC factories with a complete set of imported equipment. These are, as a rule, conveyor lines with inventory pallets, which are equipped with universal onboard elements, elements forming openings and clamps for installation of fittings and fixings with fastening to pallets on quick-release magnets [23]. Modernization of LPC factories, in our opinion, should consist in transition to flexible technological methods with minimization of costs due to the advanced planning of residential houses of a new type with the subsequent selection of technological equipment for factory production of elements of designed projects.

2. In the course of further modernization on an innovation basis, it is necessary to transform house-building factories to a panel-frame construction.

3. In those regions of Russia where industrial construction is completely absent (eight republics, districts, regions) or it produces insignificant volumes, it is necessary to create a base for such construction using a panel-frame technological scheme.

4. In the regions where the proportion of industrial housing is large enough (first of all, the Central and North-West federal districts) and there is a sufficient number of housebuilding factories and enterprises producing precast concrete, to our opinion, a modern cluster approach is needed. The main distinctive parameters of the formation and implementation of regional cluster policy compared with traditional industrial and construction policies include a territory development strategy, government and business relationships; production and technology; economic efficiency criteria; labor market; institutional environment; type of dominant communications between enterprises [24, 25]. By aggregating the most essential features of these approaches, table 1 presents the results of its comparative analysis with an emphasis on the important differences of the cluster approach.

Table 1. Main distinctive features of the cluster approach to management compared with the industrial one

\begin{tabular}{|l|l|l|}
\hline \multicolumn{1}{|c|}{ Features } & \multicolumn{1}{|c|}{ Cluster approach } & \multicolumn{1}{c|}{ Industrial approach } \\
\hline $\begin{array}{l}\text { Formation } \\
\text { principle }\end{array}$ & $\begin{array}{l}\text { Horizontal and vertical integration, } \\
\text { optimization of inter-industry } \\
\text { impacts }\end{array}$ & By technology \\
\hline $\begin{array}{l}\text { Economic growth } \\
\text { potential }\end{array}$ & $\begin{array}{l}\text { Synergy effects due to the } \\
\text { interaction of diverse elements. } \\
\text { The presence of a key participant } \\
\text { (large enterprise, research center) }\end{array}$ & $\begin{array}{l}\text { Production (industrial) } \\
\text { intensification }\end{array}$ \\
\hline $\begin{array}{l}\text { The possibility of } \\
\text { enhancing } \\
\text { innovation } \\
\text { potential }\end{array}$ & $\begin{array}{l}\text { High level of innovation activity } \\
\text { due to the possibility of } \\
\text { concentration of resources in } \\
\text { separate elements of the cluster, } \\
\text { defining its innovative potential }\end{array}$ & $\begin{array}{l}\text { Limited due to the inertia of the } \\
\text { system of innovation, } \\
\text { communication problems }\end{array}$ \\
\hline $\begin{array}{l}\text { Competitiveness } \\
\text { of regional } \\
\text { products }\end{array}$ & $\begin{array}{l}\text { Increased due to the territorial } \\
\text { concentration of cluster elements, } \\
\text { which leads to a decrease in } \\
\text { transport and transaction costs }\end{array}$ & $\begin{array}{l}\text { Poorly expressed due to the } \\
\text { territorial dispersion of } \\
\text { enterprises implementing } \\
\text { production processes within the } \\
\text { same industry }\end{array}$ \\
\hline
\end{tabular}




\begin{tabular}{|l|l|l|}
\hline \multicolumn{1}{|c|}{ Features } & \multicolumn{1}{|c|}{ Cluster approach } & \multicolumn{1}{c|}{ Industrial approach } \\
\hline $\begin{array}{l}\text { Stable regional } \\
\text { system }\end{array}$ & $\begin{array}{l}\text { Possible adaptation to changing } \\
\text { environmental conditions due to } \\
\text { higher diversification of activities }\end{array}$ & $\begin{array}{l}\text { Higher specialization leading to } \\
\text { a decrease in the adaptive } \\
\text { capacity of the regional socio- } \\
\text { economic system }\end{array}$ \\
\hline $\begin{array}{l}\text { Investment } \\
\text { potential } \\
\text { (attractiveness) }\end{array}$ & $\begin{array}{l}\text { Determined by the possibility of } \\
\text { integrated use of investment } \\
\text { resources }\end{array}$ & $\begin{array}{l}\text { Investment effect is determined } \\
\text { by the capabilities of the } \\
\text { investee }\end{array}$ \\
\hline $\begin{array}{l}\text { Communication } \\
\text { level }\end{array}$ & $\begin{array}{l}\text { Long-term communication } \\
\text { between cluster members based on } \\
\text { mutually beneficial relationships }\end{array}$ & $\begin{array}{l}\text { Rigid hierarchical structure } \\
\text { defined by technological and } \\
\text { administrative and managerial } \\
\text { relations }\end{array}$ \\
\hline $\begin{array}{l}\text { Eco-friendly and } \\
\text { energy-efficient } \\
\text { production }\end{array}$ & $\begin{array}{l}\text { Voluntary use of integrated } \\
\text { energy-saving technologies, } \\
\text { increased attention to the eco- } \\
\text { friendly production, utilization and } \\
\text { recycling }\end{array}$ & $\begin{array}{l}\text { Forced use of environmental } \\
\text { and resource-saving } \\
\text { technologies for a particular } \\
\text { enterprise without taking into } \\
\text { account the complex impact on } \\
\text { the environment }\end{array}$ \\
\hline
\end{tabular}

\section{Conclusions}

The basis for the implementation of cluster policy is the creation of conditions for synergistic effect for companies within the cluster network, as well as the identification and application of factors that influence the increase in the competitiveness of individual elements and the cluster as a whole. Since the products of the panel-frame construction system are formed on the basis of the participation of a large number of factories - from project bureau, manufacturers of structural elements (panel, frame) to construction departments for installation and finishing works [26, 27], then it is better to form the industrial housing cluster on the territory of St. Petersburg and the Leningrad Region, covering all or most of the profile enterprises.

Thus, the creation of such cluster, first in St. Petersburg and the Leningrad Region, and then in other regions of Russia, will ensure regional interest in the production of highquality, cost-effective house-building products improving an architectural appearance of residential buildings, and generally developing an affordable housing market that will speed up the solution of the housing problem in the country.

\section{References}

1. T. Maleeva, Prospects for development of agglomerations in Russia, Theory and practice of social development, 10, 124-126 (2014)

2. V. Rakova, A. Chalenko, et al, The state's participation in solving housing problem of citizens in modern conditions, Fundamental research, 12(4) 823-827 (2015)

3. Urban Reports - Urban strategies and visions in mid-sized cities in a local and global context (GTA Publishers, Chicago, 2009)

4. N. V. Vasileva, L. G. Selyutina, Development of housing fund's reproduction forms: a terminological aspect of the problem, News of higher educational institutions. Construction, 1(529), 114-118 (2003) 
5. V. A. Martynov, Innovation processes in construction: formation of the system of investment of innovation processes, Problems of modern economy, 3(55), 261-264 (2015)

6. K. O. Bulgakova, L. G. Selyutina, Basics of investment projects selection for the implementation of regional investment programs in the sphere of social house building, Espacios, 39 (26) (2018)

7. E. Evseeva, A. Martynova, Social housing construction in Russia: reality and development prospects, Science Review, 21, 218-220 (2015)

8. T. V. Maleeva, Modern directions and methods of studying the demand for services in the sphere of housing, European Social Science Journal, 4(32), 436-444 (2013)

9. M. A. Egorova, K. O. Bulgakova, L. G. Selyutina, Modelling of investment processes in the sphere of social house building. International Conference Proceedings 2017 Innovations in science and education, 67-72 (Central Bohemia University, Prague, 2017)

10. Regions of Russia (Rosstat, Moscow, 2018)

11. T. V. Maleeva, L. G. Selyutina, Analysis and evaluation of financial resources of social housing construction in city, Materials Science Forum, 931, 1118-1121 (2018)

12. A. A. Ladnushkin, R. R. Avkhadeev, et al, Analysis of the use of reinforced concrete slabs for industrial buildings for the technology of screenless mounting while modernizing existing production facilities, News of the Kazan State University of Architecture and Civil Engineering, 1(35), 233-239 (2016)

13. N. V. Dubynin, From Large-Panel Housing Construction of the XX Century to System of Panel-Frame Housing Construction of the XXI Century, Housing Construction, 10, 12-20 (2015)

14. M. Schoenwitz, A. Potter, et al, Product, Process and customer preference alignment in prefabricated house building International, Journal of Production Economics, 138, 7990 (2017)

15. F. Meuser, Ten Parameters for Standard Houses. Peculiarities and Prospects of Panel House Building in the XXI Century, Housing Construction, 5, 52-55 (2015)

16. A. Kayello, H. Ge, et al, Experimental study of thermal and air tightness performance of structural insulated panel joints in cold climates, Building and Environment, 115, 345-357 (2017)

17. S. Shogenov, A. Balov, et al, The engineer's messenger of the Don, 2(41), 66 (2016)

18. S. Nikolaev, The revival of large-panel housing in Russia, Housing Construction, 4, 2 8 (2012)

19. V. V. Buzyrev, The Housing problem and its solution in modern conditions (St. Petersburg State University of Economics, St. Petersburg, 2013)

20. A. Magay, The current state and prospects of development of large-panel housing construction in Russia, Construction materials, equipment, technologies of the XXI century, 2, 40-42 (2015)

21. S. Nikolaev, A. Shreiber, V. Etenko, Panel and frame housing construction - a new stage of development of efficiency, Housing Construction, 2, 3-7 (2015)

22. D. Dissanayake, C. Jayasinghe, et al, A comparative embodied energy analysis of a house with recycled expanded polystyrene (EPS) based foam concrete wall panels Energy and buildings, 135, pp 85-94 (2017)

23. D. Kovalev, Methods of upgrading the facades of large-panel houses, Modern problems of science and education, 2(2), 875 (2015)

24. D. Rodionov, A. Afanasov, et al, Regional cluster policy in the context of managing the development of the regional economy, World of economics law, 4-5, 19-30 (2014)

25. M. A. Egorova, Financial aspect of effective management theory, Society Environment Development (Terra Humana), 3(12), 11-17 (2009) 
26. L. G. Selyutina, Innovative approach to managerial decision-making in construction business, Materials Science Forum, 931, 1113-1117 (2018)

27. N. V. Vasileva, T.V. Maleeva, L. G. Selyutina, N. N. Frolova, Special characteristics of market supply formation in housing development sector and residential buildings reconstruction under the present-day conditions in Russia. International Conference Proceedings 2019 - Innovations in science and education (Czech Republic, Prague, 2019) 